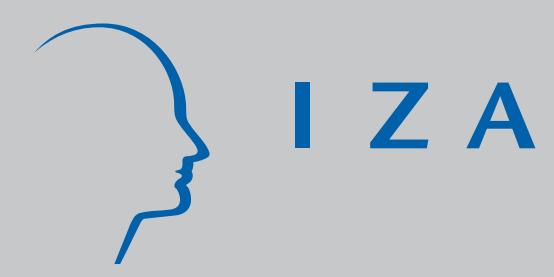

IZADP No. 2984

Are All Democracies Equally Good?

The Role of Interactions between Political

Environment and Inequality for Rule of Law

Uwe Sunde

Matteo Cervellati

Piergiuseppe Fortunato

August 2007 


\title{
Are All Democracies Equally Good? The Role of Interactions between Political Environment and Inequality for Rule of Law
}

\author{
Uwe Sunde \\ IZA, University of Bonn \\ and CEPR \\ Matteo Cervellati \\ University of Bologna, IAE Barcelona \\ and IZA \\ Piergiuseppe Fortunato \\ University of Bologna and United Nations
}

Discussion Paper No. 2984
August 2007

IZA

P.O. Box 7240

53072 Bonn

Germany

Phone: +49-228-3894-0

Fax: +49-228-3894-180

E-mail: iza@iza.org

Any opinions expressed here are those of the author(s) and not those of the institute. Research disseminated by IZA may include views on policy, but the institute itself takes no institutional policy positions.

The Institute for the Study of Labor (IZA) in Bonn is a local and virtual international research center and a place of communication between science, politics and business. IZA is an independent nonprofit company supported by Deutsche Post World Net. The center is associated with the University of Bonn and offers a stimulating research environment through its research networks, research support, and visitors and doctoral programs. IZA engages in (i) original and internationally competitive research in all fields of labor economics, (ii) development of policy concepts, and (iii) dissemination of research results and concepts to the interested public.

IZA Discussion Papers often represent preliminary work and are circulated to encourage discussion. Citation of such a paper should account for its provisional character. A revised version may be available directly from the author. 
IZA Discussion Paper No. 2984

August 2007

\section{ABSTRACT}

\section{Are All Democracies Equally Good? The Role of Interactions between Political Environment and Inequality for Rule of Law}

Using cross-country data, we find evidence for a significant negative interaction effect between democracy and inequality in determining the quality of growth-promoting institutions like rule of law. Democracy is associated with institutions of higher quality when inequality is lower.

JEL Classification: $\quad$ O43, P48, P14

Keywords: inequality, democracy, institutions, rule of law, interactions

Corresponding author:

Uwe Sunde

IZA

P.O. Box 7240

D-53072 Bonn

Germany

E-mail: sunde@iza.org 
The quality of economic institutions, in particular property rights protection and rule of law, are considered crucial for economic development. ${ }^{1}$ The empirical debate about the determinants of high quality economic institutions is still ongoing. Numerous findings point at the central role of inequality for the quality of rule of law. ${ }^{2}$ The role played by democracy for the implementation of high-quality institutions has also attracted increasing attention. Theories of endogenous democratization either postulate a positive relationship between democracy and economic development, or leave open whether democracy implies better economic institutions. ${ }^{3}$ The empirical literature has documented a large variability in the quality of rule of law across democracies, but overall the findings support a positive effect of democracy on institutional quality. 4

While both inequality and democracy affect the quality of rule of law, the role of interactions between inequality and democracy for institutional quality has not been studied. Already de Tocqueville (1835, Second Book, Chapter I), warned of the possible dangers associated with democracy in societies characterized by large economic disparities. As ideal state he describes a democracy with perfect equality and freedom, but he also notices the potential problems of larger political equality without the appropriate economic environment, which may lead to a "tyranny of the majority". In other words, if social and economic conditions are unequal, democracies granting more equal political influence may entail excessive redistributive pressure or even public expropriation, thereby reducing private property rights protection, and distorting the incentives for individual entrepreneurship. Reversing this argument, a good rule of law may be more easily implemented under the oligarchy of a rich elite if inequality is high (similar to the Hobbesian view of a Leviathan). The hypothesis emerging from this view is that the interaction between inequality and democracy might crucially affect institutional quality: Democracies, as compared to oligarchies, might implement better rule of law if inequality is low, while the reverse may hold if inequality is high. ${ }^{5}$

This paper extends the empirical literature by investigating whether such an interaction between inequality and democracy indeed determines the quality of rule of law. We use available cross-country data and estimate the relation between institutional quality and different measures of economic equality and democracy. As in previous studies, countries with lower inequality and

\footnotetext{
${ }^{1}$ See Knack and Keefer (1995), Hall and Jones (1999), Rodrik et al. (2004), Rigobon and Rodrik (2005).

${ }^{2}$ See Chong and Calderon (2000), Keefer and Knack (2002), Gupta et al. (2002), Chong and Gradstein (2007).

${ }^{3}$ See, e.g., Acemoglu and Robinson (2005).

${ }^{4}$ See Barro (2000), Rodrik and Wacziarg (2005).

${ }^{5}$ Cervellati et al. (2007) present a model that formally derives the prediction that political institutions, like democracy, only matter for growth-enhancing institutions in conjunction with economic conditions, like inequality.
} 
better democracies exhibit better rule of law. We then extend the specification adding an interaction to investigate how democracy affects growth-enhancing institutions in conjunction with economic inequality. We find that institutional quality is significantly affected by the interaction between the quality of democracy and equality.

\section{Data Description}

We primarily use the cross country data constructed by Easterly (2001) and by Persson and Tabellini (2004). As measure of democracy, the data contain averages of the Freedom House indices of civil liberties and political rights (Gastil) over the period 1990 and 1998 that range from 1 to 7 , where lower values indicate better institutions. The Persson-Tabellini data only includes 85 democracies that satisfy a minimum requirement of civil liberties and political rights with a Gastil not exceeding a value of 5. As measures of (in-)equality, the data contains information on the average income share of the 2nd, 3rd and 4th income quintile over the period 1960 and 1996, and the average Gini-coefficient of income in the 1980s and 1990s. The data also contain detailed information on historical determinants of institutions, like colonial and legal origin. ${ }^{6}$

We use measures for the quality of rule of law from different data sources. In particular, we use the standardized point estimates of the fifth cluster (rule of law) of the World Bank measures of institutional quality and governance, which "measure the success of a society in developing an environment in which fair and predictable rules form the basis for economic and social interactions, and importantly, the extent to which property rights are protected" (see Kaufmann et al., 2004, p. 4). As alternative measure, we use the "rule of law" variable provided by the International Country Risk Guide (ICRG), which reflects the degree to which the citizens of a country are willing to accept the established institutions to make and implement laws and adjudicate disputes on a scale from 0 to 10 . Lower scores indicate a tendency for using physical force or illegal means to settle claims, see Knack and Keefer (1995). As third measure, we use the composite index of government anti-diversion policies, GADP, which includes an average over the categories law and order, bureaucratic quality, corruption, risk of expropriation, and government repudiation of contracts, see Hall and Jones (1999). All data are averages for the years 1985-1995. Higher values of any of the rule of law or GADP variables imply better institutions.

\footnotetext{
${ }^{6}$ To have two measures of equality we generate a reversed Gini-Index variable by subtracting the Gini from 100. Also, we generate an oligarchy indicator that takes the value 1 if a country is not democratic according to the definition by Persson and Tabellini (2004) based on the Gastil index.
} 


\section{Results}

We first run OLS regressions with the quality of economic institutions (rule of law) as dependent variable. Explanatory variables are three alternative measures for oligarchic political institutions (an oligarchy indicator, the Freedom House index for civil liberties, and the Freedom House index for political rights) and two alternative measures of equality (the middle class income share and the reverse Gini index). Additional controls include tropical location and an indicator for oil exporting to account for geographic factors that might drive the results (see Easterly, 2001), as well as an index for ethno-linguistic fractionalization (Easterly and Levine, 1997, Easterly, 2001; Persson and Tabellini, 2004). The results are presented in Table 1. The findings compare to those in the literature: (better) democracies (granting their citizens more civil liberties and political rights) and more equal countries exhibit better rule of law and GADP.

Table 2 presents the results of regressions of a model including an interaction term between oligarchic institutions and equality. The first four columns use the World Bank measures of rule of law, columns (5) to (8) use the ICRG rule of law variables, and columns (9) to (12) use the GADP measure as dependent variable. Across all specifications, the results reveal a weak positive effect of oligarchic institutions on the quality of economic institutions. Equality has a strong positive effect. Most strikingly, the interaction between oligarchy and equality is negative and significant in all cases. Further experiments reveal that these results are robust to changes in the specification. ${ }^{7}$

\section{Discussion}

Our findings reveal non-monotonic effects of inequality and political institutions: The significant negative interaction term implies that oligarchies are less likely to implement a rule of law the more equal the society or, in other words, democracies are more likely to implement good rule of law when inequality is low. Intuitively, the reference group for the interpretation of the results is a democracy with low equality. Compared to this reference, an increase in equality is detrimental for economic institutions if it is associated with a switch to oligarchy. Vice versa, more equality improves economic institutions under democracy, not oligarchy. The strong and significant positive coefficient of equality implies that, compared to very unequal democracies, a decrease in inequality implies better economic institutions: Higher equality increases the likelihood of good

\footnotetext{
${ }^{7}$ In particular, the interaction remains significant when considering the reverse Gini instead of middle class share, or including dummy variables for colonial and legal origin, as suggested by Persson and Tabellini (2004) or La Porta et al. (2004).
} 
economic institutions in countries with good democratic institutions. Finally, more oligarchic institutions are, conditional on equality and the interaction term, conducive for better economic institutions. This result contradicts the conventional wisdom from a standard regression without interaction, according to which democracies are associated with better outcomes. The results instead indicate that democracy by itself is not necessarily conducive to institutional quality without reference to the economic environment in terms of inequality.

Clearly, cross-country regressions have to be interpreted with caution. Measurement error, unobserved heterogeneity and endogeneity have not been addressed explicitly. Nevertheless, these problems are unlikely to drive our main result. We apply the specification conventionally used in the literature with all the controls that are usually added. The findings in Table 1 are closely in line with those of the literature and hold for different measures of institutional quality and inequality, as do the results on the negative interaction effect in Table 2. Also, it is not obvious to find an argument for how endogeneity may give rise to a consistently negative interaction coefficient. If anything, our main finding of a significant interaction between inequality and democracy raises concerns about the specification of earlier empirical models that omit interactions and exclude the possibility of a non-monotonic relationship between inequality, and political and economic institutions.

Economically, the results raise a note of caution concerning models that treat good economic institutions and democratic regimes as synonyms. The findings illustrate the importance of taking the economic environment, and in particular the degree of inequality, into account when gauging the potential advantages of implementing democracy for fostering economic development. Finally, the results suggest the need for a deeper understanding of the determinants of institutional quality, and for further empirical and theoretical research on the interactions between the economic environment and different institutions. 


\section{References}

Acemoglu, D., and J. Robinson (2005): Economic Origins of Dictatorship and Democracy. Cambridge University Press, Cambridge.

Barro, R. J. (2000): "Rule of Law, Democracy, and Economic Performance," in 2000 Index of Economic Freedom, ed. by M. Miles, and et al. The Heritage Foundation, Washington.

Cervellati, M., P. Fortunato, and U. Sunde (2005): "Hobbes to Rousseau: Inequality, Institutions, and Development," Economic Journal, forthcoming.

Chong, A., and C. Calderon (2000): "Institutional Quality and Income Distribution," Economic Development and Cultural Change, 48, 761-786.

Chong, A., And M. Gradstein (2007): "Inequality and Institutions," Review of Economics and Statistics, forthcoming.

De Tocqueville, A. (1835): Democracy in America. Gosselin, Paris.

Easterly, W. (2001): "The Middle Class Consensus and Economic Development," Journal of Economic Growth, 6(4), 317-335.

Easterly, W., and R. Levine (1997): "Africa's Growth Tragedy: Policies and Ethnic Divisions," Quarterly Journal of Economics, 112(4), 1203-1250.

Gupta, S., H. Davoodi, and R. Alonso-Terme (2002): "Does Corruption Affect Income Inequality and Poverty?," Economics of Governance, 3(1), 23-45.

Hall, R. E., and C. I. Jones (1999): "Why Do Some Countries Produce So Much More Output Per Worker Than Others?," Quarterly Journal of Economics, CXIV(1), 83-116.

Kaufmann, D., A. KraAy, and M. Mastruzzi (2004): "Governance Matters III: Governance Indicators for 1996-2002," World Bank Research Paper, April 5, 2004.

Keefer, P., and S. Knack (2002): "Polarization, Politics, and Property Rights: Links Between Inequality and Growth," Public Choice, 111, 127-154.

Knack, S., and P. Keefer (1995): "Institutions and Economic Performance: Cross-Country Tests Using Alternative Institutional Measures," Economics and Politics, 7, 207-227.

La Porta, R., F. Lopez-de Silanes, C. Pop-Eleches, and A. Shleifer (2004): "Judicial Checks and Balances," Journal of Political Economy, 112(2), 445-470.

Persson, T., and G. Tabellini (2004): "Constitutional Rules and Fiscal Policy Outcomes," American Economic Review, 94(1), 25-45.

Rigobon, R., and D. Rodrik (2005): "Rule of Law, Democracy, Openness and Income: Estimating the Interrelationships," Economics of Transition, 13(3), 533-564.

Rodrik, D., A. Subramanian, and F. Trebbi (2004): "Institutions Rule: The Primacy of Institutions over Geography and Integration in Economic Development," Journal of Economic Growth, 9, 131-165.

Rodrik, D., and R. Wacziarg (2005): "Do Democratic Transitions Produce Bad Economic Outcomes?," American Economic Review, 95(3), 50-55. 


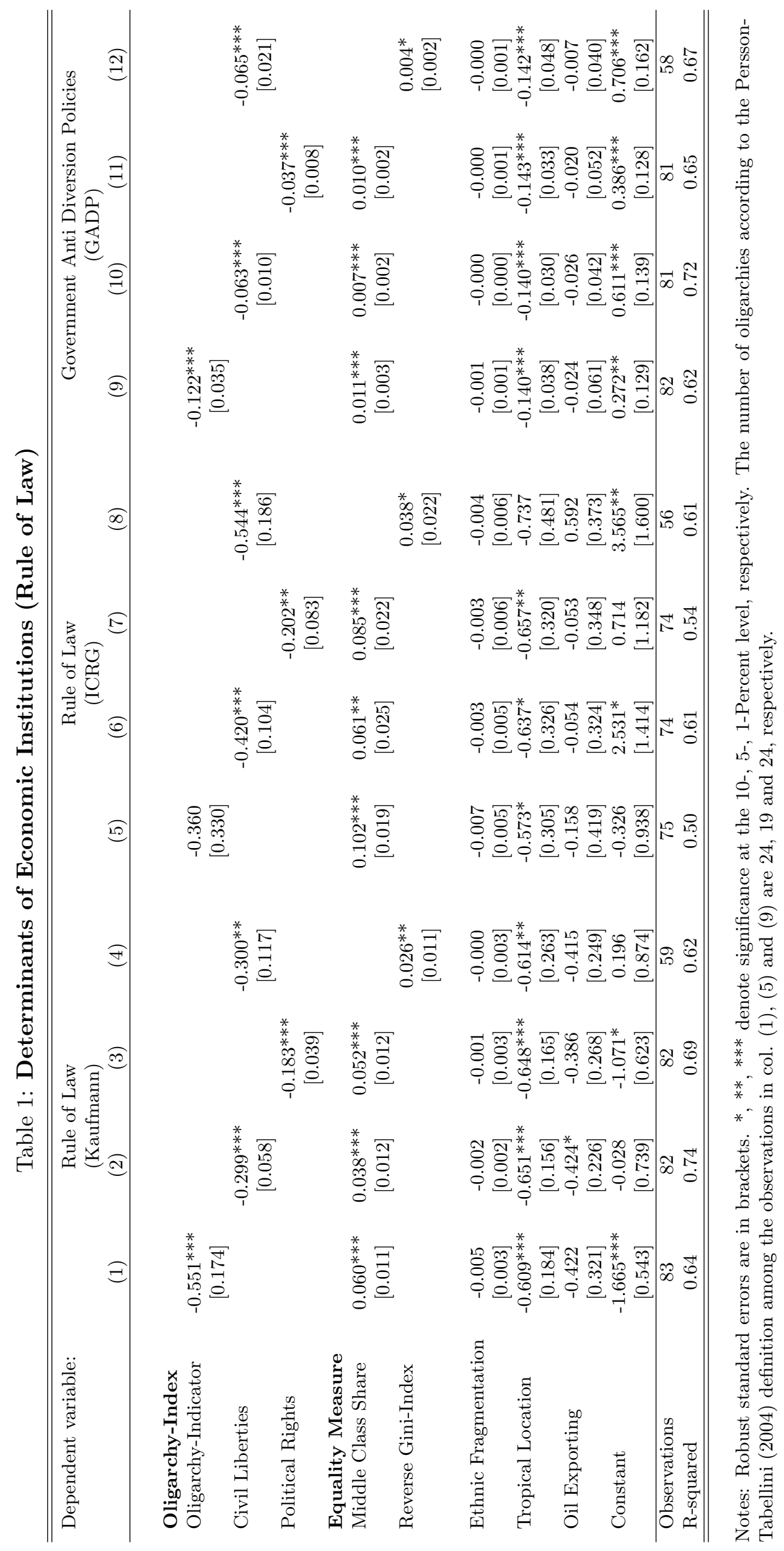




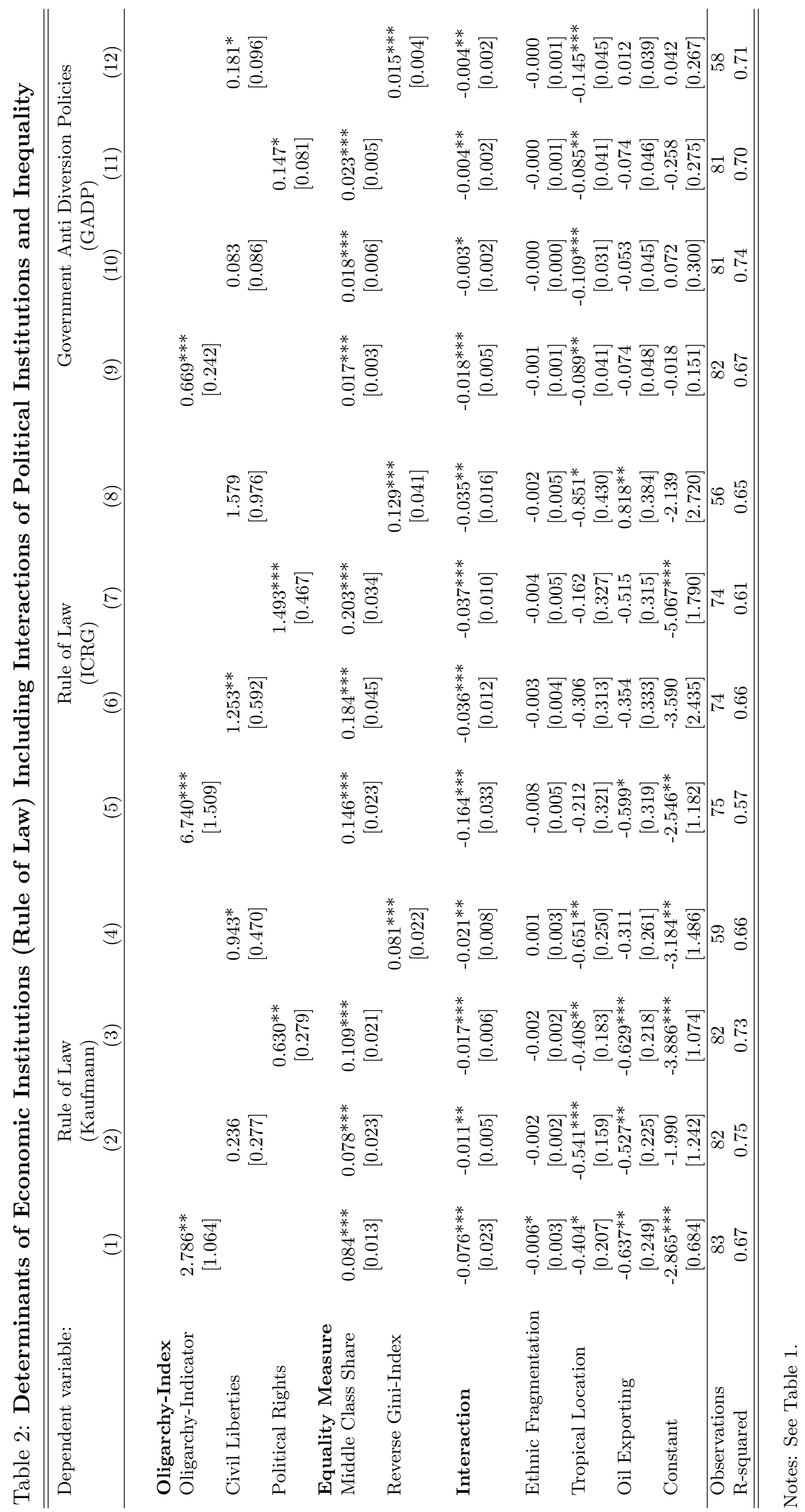

